\title{
Safety and Comfortableness of Playing as the Manifestation of Child Friendly Kampung. Case Study of Kampung Badran Yogyakarta
}

\author{
Hastuti Saptorini ${ }^{1}$ and Heri Apricilia- \\ ningtyas $^{2}$ \\ ${ }^{1}$ Department of Architecture , Faculty of Civil Engineering and Planning, \\ Universitas Islam Indonesia, Yogyakarta \\ 2 Department of Architecture , Faculty of Civil Engineering and Planning, \\ Universitas Islam Indonesia, Yogyakarta
}

\author{
Article History \\ Received : 07 April 2017 \\ Accepted : 24 May 2017 \\ Published: 30 Oktober 2017
}

\begin{abstract}
Limited space in densely populated area in cities becomes threat for safety and comfortableness for children need for outdoor playground. Kampung Badran in Yogyakarta has been declared as one of the children friendly kampungs. Thus, it is necessary to examine the parameters and indicators of safety and comfortableness to move based on the standard. This paper aims to study the level of safety and comfortableness in the playing space of children in the kampung as the manifestation of children friendly kampung. The data was collected by observing and taking photographs and analyzed with descriptive analytical method. The findings show that the conditions of facilities in the form of space are relatively adequate and safe. However, the condition of playing equipment and facilities are not safe and lacking of treatment. The children who are playing are prone to potential accidents such as sinking in, jammed in, and slippery. The participation of stakeholders in maintaining and developing the Kampung is highly needed because the kampung has potential assets to be example and role model for other kampung to achieve Children Friendly Kampung.
\end{abstract}

Keywords: children safety, movement comfortableness, children friendly Kampung

\section{Introduction}

Scarcity of space for children outdoor playground has been acute problems of urban area. Consequently, the safety and comfortableness of children while playing are threatened, especially those living at kampungs in big cities. Kampung Badran in RW 11, Jetis, Bumijo, Yogyakarta also experienced such problem. Although the government has declared this kampung as Children Friendly Kampung, the area that is located next to the riverbank of Winongo River needs attention in the aspect of

Correspondence: Hastuti Saptorini

Department of Architecture , Faculty of Civil Engineering and Planning, Universitas Islam Indonesia, Yogyakarta.

E-mail: hastutisaptorini@yahoo.com safety and comfortableness. Thus, the criteria of safety and comfortableness for children to play should be formulated in order to realize the spirit of government to achieve children friendly kampung.

Studies about Kampung have been done by several researchers. In her master thesis, Ika Pasca Himawati (2013) stated difference view the program of Children Friendly Kampung (CFK). Generally, CFK program is a form of transformation to response social problems related to children. The people of Kampung perceived that CFK program is not final even if the government has proposed the idealism of the program. 
Kharisma (2015) also discussed about Kampung in a research entitled "Kampung Badran as Children Friendly Kampung to Achieve Yogyakarta as a Children Friendly City". The re-search found three main findings. The first is the Kampung was selected by the government for CFK program because the Kampung has many programs and achievement. The second is children interaction is built in the kampung during the commemoration of big events or festival. The third is the frequency of child abuse in the Kampung has decreased. In addition, the children have been involved in decision making process in the kampung.

Lutfiani (2015) also conducted research in Kampung Badran entitled "The Characteristics and utilization of Playing Space in Kampung Badran, Yogyakarta". Matched with the research objectives, this study found several new findings. Firstly, there are two categories of playing in the Kampung, i.e. formal and informal. Secondly, there are physical and nonphysical factors in determining the location to play. The physical factor is the distance of playing location with the children's residence that is relatively close. The non physical factor is the people who are playing with them.

\section{Research Methodology}

Research found that $75.8 \%$ of 202,970 accidents were caused by playing equipment that is installed in the public space. The equipment that causes accidents is related to several parameters such as quality of construction, materials, and the connection in each of the node.

How is the condition of Kampung Badran Yogyakarta? As a kampung that has been declared as the model of Children Friendly Kampung, has the factor of safety and comfortableness been fulfilled in the playing space? Does Kampung Badran deserve the status as CFK? These questions become the basis of this research objective i.e. to identify the level of safety and comfortableness of children playing space in Kampung Badran as CFK. Thus, this finding can be proposed as inputs for stakeholders and decision makers in Yogyakarta City in preparing the strategy for maintenance and development. In Malang City, the variable of safety and comfortableness has been studied by Hutapea et al (2015).

The location of the research object is RW 11 Kampung Badran, Jetis, Bumijo, Yogyakarta. The population of this research is the children playing space in Kampung Badran. The sample was taken using purposive sampling method i.e. the playing facilities used by children from the age of 3-10 years old in playing area of Kampung Badran. Data related with safety, security, and comfortableness to move was gathered with three ways, i.e. literature review, observation, and taking photographs. The collected data were then analyzed with descriptive analytic method in which the data were categorized according to the research parameter, which is based on the criteria of security, safety, and comfortableness of children to move while playing. Afterward, the findings were described in relation to the criteria of Children Friendly Kampung.

\section{Children Friendly Kampung}

Children Friendly Kampung (CFK) is development on the basis of kampung in the unit of RW that integrate local commitment and resources to fulfill the need of children, to protect children from violence, exploitation, discrimination, and to accommodate the voice of children with careful, holistic, and sustainable ways (Aprilian, 2015). In other words, the priority of friendliness is addressed to rights of children in achieving life happiness through playing. With this way, the life of children can be built well from the aspects of cognitive, affective, and pyschomotoric. This argument is supported by Moeslichatoen in Ambiyak (2011) stating that playing is fun activity for children because it will increase knowledge, enhance social relations, make more friends, improve language skills, and building physical fitness through physical activities. 


\section{Typology of Playing}

The typology of playing based on the phases of children growth as follows (Baskara, 2009):

\section{0-3 Years Old}

At this phase, the children tend to play alone and experiment with tactility, vision, and audio. They are happy to play sands, clay, water, swing, and slides.

\section{3-6 Years Old}

At this phase, children start to have social awareness. They enjoy activities to present something such as playing with abstract element, table, chairs, slides, and other moving elements.

\section{6-8 Years Old}

At this phase, children tend to enjoy activities that create movement and action or activities that build the organizational and physical activities.

\section{8-10 Years Old and Above}

At this phase, the children are almost in the age of adolescent. They love to do activity ingroup without monitoring or intervention from the younger children.

\section{Safety in Playing}

Safety in the context of playing is free from danger so it has the security assurance and secured means safe. Thus, safety is the situation free from both psychological and physical danger from the third party and from the environment or neighborhood of the children (Diyanti, et al, 2014).

\section{Components of Safety in Playing}

The five components of safety in designing playground are as follows (Baskara, 2009):

\section{Location}

A safe location is an area where there are fence around the location for protection and there is limitation of users who use the playing space to minimize threat from outside the location. For the children safety, the location should not have direct contact with vehicle (cars/motorcycle) traffic.
2. Layout

Safe layout will enable supervision from parents, separation, or zonation of activity, age group, and kind of games.

3. Playing Equipment

The playing equipment should consider the condition of the surface corner. Curve or bend angle is the safest for playing equipment.

4. Construction

The power of construction material in the calculation should be bigger than the maximal load of total children who play altogether in one time.

5. Materials

The material with soft texture is the safest tools especially to have direct contact with the children skin. The materials for stepping and holding (handle) should help to avoid slippery when used by the children. In addition, in the area that involves motoric movement, the material should not have higher risk of accident for the children.

Olds in Diyanti, et al (2014) stated that the safety of playing could be enhanced when the designer of the playing area considers followings aspect:

1. The placement of playing facilities The placement of playing facilities can be considered safe if it is integrated with the gathering place of heterogonous community. This allows the supervision from parents towards their children while playing.

2. Circulation management

Dead end circulation in the building will cause difficulty for visual and physical access to the space that makes it a dead space.

3. Visual Access

Some elements in the playing area are needed to enable supervision from outside the activity area. 


\section{Comfortableness to Move}

Comfortableness to move is the ideal condition between anthropometry of human body and activity adjusted with the function of the space. A space in the environment should fulfill the requirement of anthropometry, differentiation, and classification of function for human activities. (Diyanti, et al, 2014).

Baskara (2009) also highlighted that the comfortableness of children to move can be influenced by following five components:

\section{Location}

Playing location is best located in the area with microclimate by utilizing area that is covered by vegetation or building structure.

\section{Layout}

The layout should allow children to move freely and enable them to choose the kind of games they want to play. There should be covered or shaded area, open area, and rest area facilities. Every area should have special definition that is different by considering the clear borders, situation, and the materials of space element based on the activities for easier identification.

3. Playing tools

The regulation of minimum and maximum dimension in the moving space is needed for every tool used by children while playing to ensure comfortableness for all ages and physical condition of the children. Olds in Diyanti et al (2014) added that the playing space should have dimension that match activity capacity in both private and public area. The grouping of activities based on the type is regulated based on the need of physical element to help the development of motoric, structure play, dramatic, and imaginative skills of the children.

4. Construction

The construction of the playing area is the components of construction design with less protrusion because it may disturb the comfortableness of the children while playing.

5. Playing Tools: Materials and Dimension The materials that are considered comfortable for playing are materials with high endurance, hygienic, and easy for maintenance. Anthropometrically, the dimension of playing tools should be adjusted with the need and size of children body based on their age and development phase.

\section{Location \& Access to Playing Area}

Figure 1. Location and access to the playing area (Source: Saptorini and Apricilianingtyas, 2015)

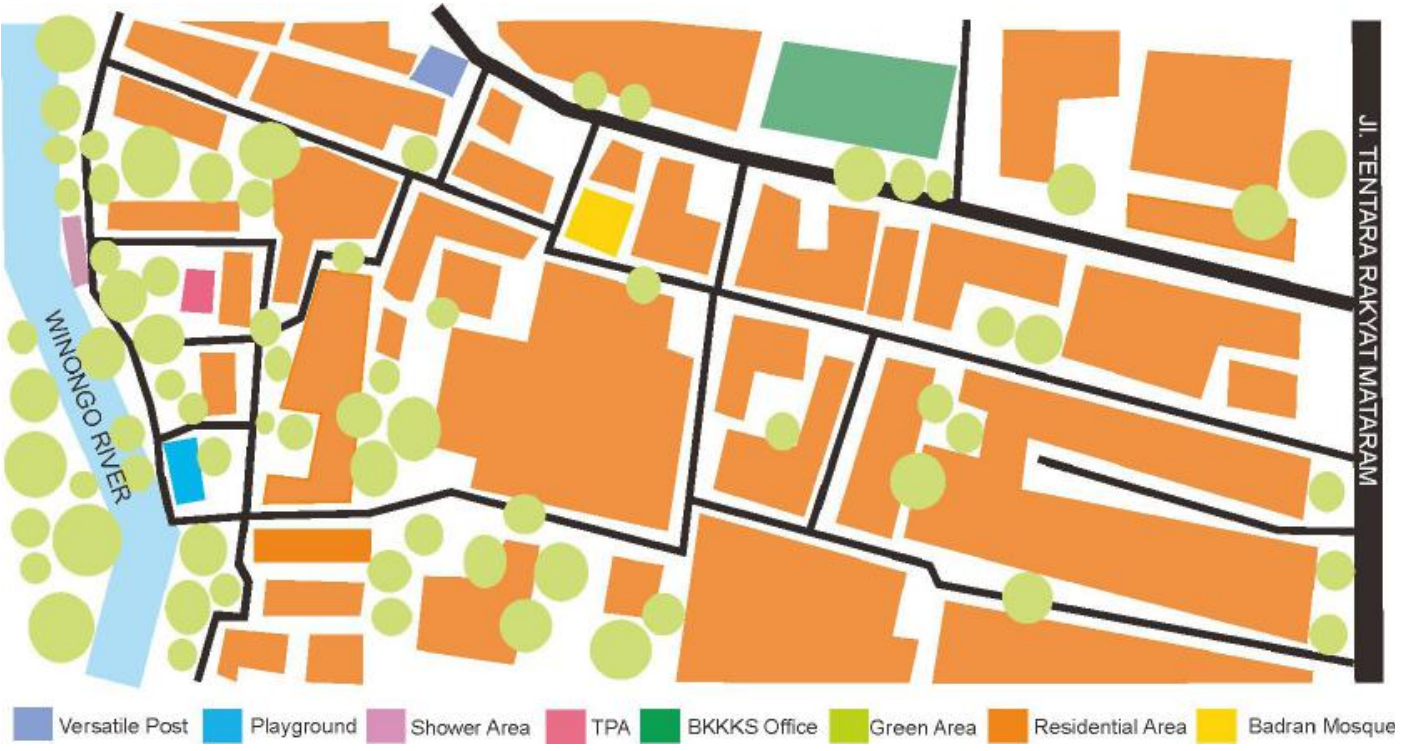


Location and access of playing area for children in Kampung Badran is located in the lowest position in the residence. This allows the parents to supervise their children while playing. The location, which is far from public, makes it relatively safe from threat of external crime from outside the Kampung. As can be seen from figure 1, the location and access of children playing area in Kampung Badran is relatively safe and accessible for the children in the Kampung. Many ways to access the place make it easy for anybody to come to the area.

From the sustainability aspect, this location can be maintainable. However, there should be bounder to the river to ensure the safety.

Figure 2. Bathing area without bounder (Source: Saptorini and Apricilianingtyas, 2015)

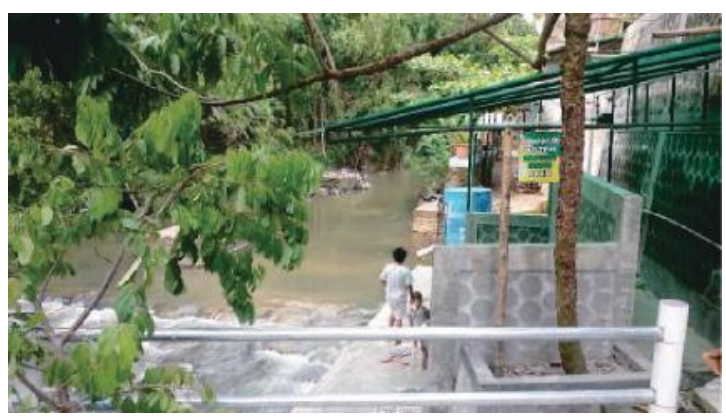

Figure 2 illustrated that the bathing area for kids near the riverbanks. Since the position in Winongo River may have strong stream during rainy seasons, the safety issue should be taken into account. The bounder of the river was not available so this area has danger potential for children.

The location of the playing area has a quite steep elevation that requires stairs to achieve the place. The height of the stairs is ranging between $8 \mathrm{~cm}$ to $20 \mathrm{~cm}$ (Figure 4). The inconsistence of stairs may cause stubbing for the children. Figure 3 illustrated the general overview of the elevation and the condition of stair (figure 4) that is used for circulation access to the playing area.
Figure 3. Elevation scheme of playing area with the residence (Source: Saptorini and Apricilianingtyas, 2015)

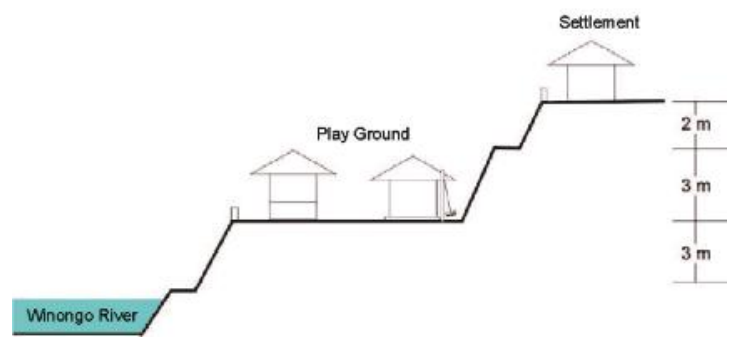

Figure 4. Design of stairs that connect playing area with the residence (Source: Saptorini, 2015)

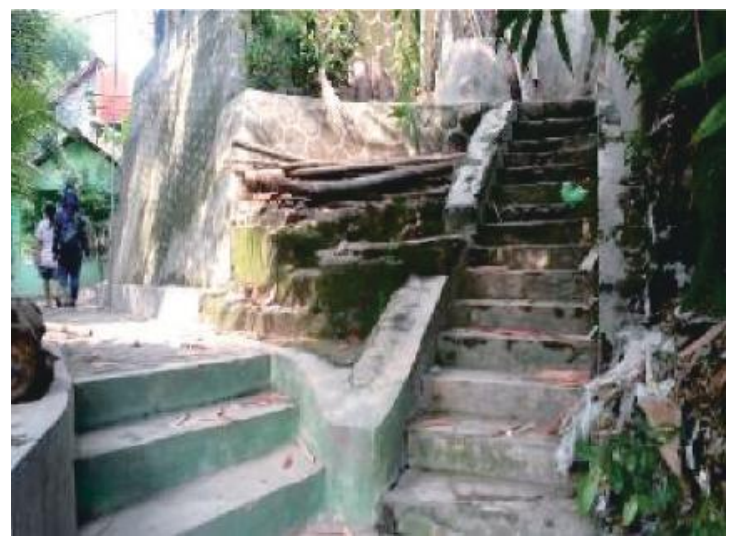

\section{Shading of Playing Area}

Figure 5. Stage gazebo with height of 0.6 meter (Source: Saptorini, 2015)

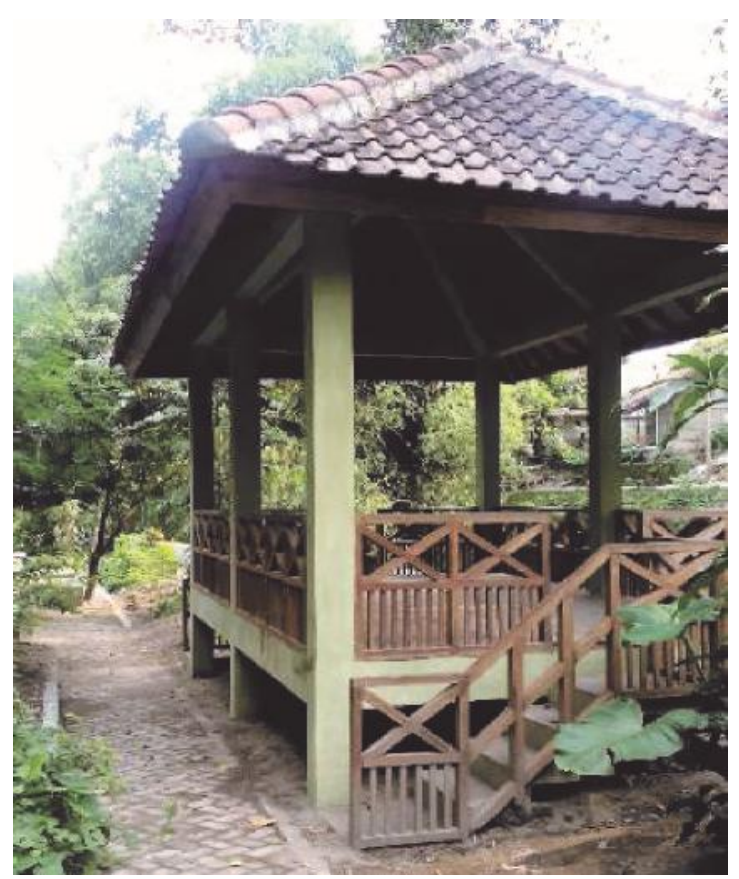


Figure 5 shows the gazebo used by children for gathering and shading during hot or rainy weather. This building uses stage style with the height of 0.6 meter with floor made of bamboo materials. This height is relatively safe for children with the age of 3-10 years old. They can relax while seating or laying down for sharing stories or playing experience. However, the construction of the floor starts to decay and no longer safe for children. The children may potentially get slipped in or jammed the floor. The same situation also applies to other gazebo. The installation of bamboos is not really well arranged because it has some gaps and some nails that may potentially hamper the movement of the children.

\section{Facilities / Playing Tools}

Figure 6. Swing with Iron material and wood that started to decay may cause danger to the children (Source: Saptorini, 2015).

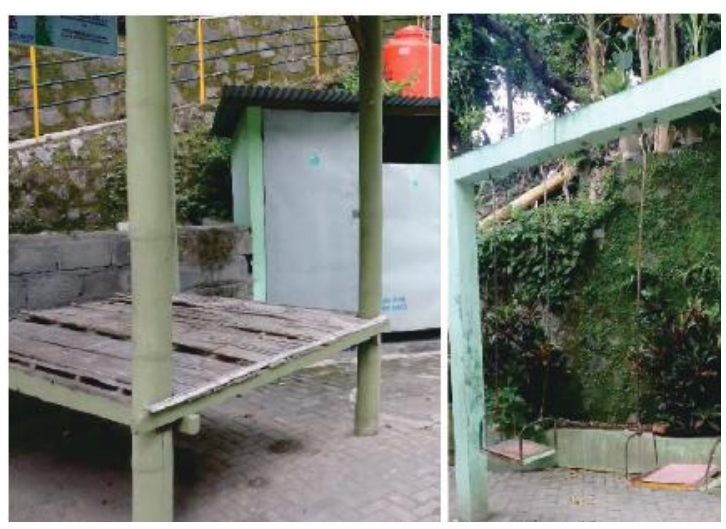

The available facilities or equipment for playing are quite various such as swing, slides, swimming pool, etc. that have become the favorite among the children. The swing (Figure 6) is made of frame with iron material and wooden seat. However, the metal that supposed to move in dynamic style is yet rot and corrosive. The seat is also decayed that may potentially cause accident. This also happened to the slides in the swimming pool (figure 7). The seat started to decay because of exposure to sun and rain that make it not safe for children. The slides also do not have railing so it is a bit dangerous for children to slide in group.
Figure 7. Slides in the swimming pool started to decay and it may potentially causes jammed in (Source: Saptorini, 2015)

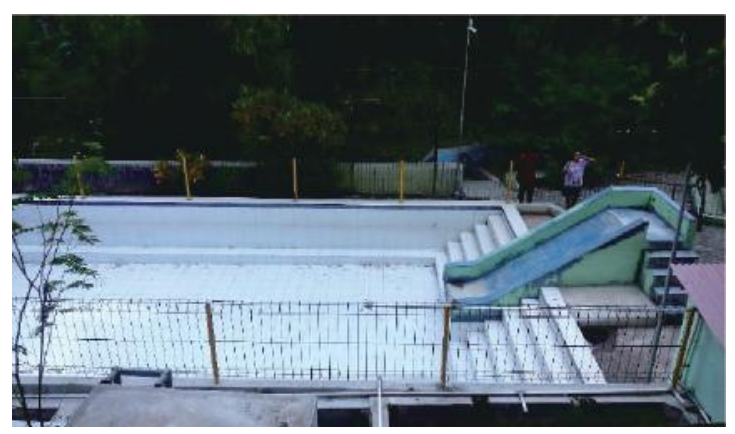

\section{Comfortableness to Move}

The access from one facility to another is quite easy with the help of stairs and ramp. The width of the street in the playing area is 1-2 meter, which is still convenient to be passed by one child for 1 meter. The swing distance of 1.5 meter back and forth is quite safe since it will not disturb each other's movement.

Some dimension of playing facilities does not pay attention to the anthropometry of the children aged 3-6 years. The swing seat with the height of 0.5 meter with hexagon shape is not convenient for 3-6 years old children because the distance does not match their size of bodies.

\section{The Effort of Kampung Badran to be Children Friendly Kampung}

The effort of Kampung Badran to be CFK can be indicated by the condition of the playground area. Based on the definition and goals of the government, principles of friendliness towards children are realized through acknowledgement of children's rights in building their selfesteem completely in the place where they live. Children life cannot be separated from playing as the way to build themselves from the cognitive, affective, and psychomotoric aspect. The world playing makes them happy and free from threat and danger in the playing area as the media and the playing tools as the facilities. 
In the context of existence of playing space, Kampung Badran has accommodated the need optimally. The allocation of playing area in some open space has been accessible for the children in Kampung Badran. However, the quality of access such as the design of stairs needs to be evaluated and adjusted. The angle of stairs, maximum numbers of stairs, the height of antrede, the width of optrede, the texture of floor material, footstep, etc. Should be standardized. One important thing that needs serious attention in the playing location is the absence of bounder in form of physical fence with Winongo River. This situation may potentially threat the safety and security of children while playing. Supervision or monitoring from parents is not a layout and systemic based safety model. The concept of riverside layout could be used as anticipatory model that is by creating several activities that involve the whole age groups in forms of business, recreation, sport, and education.

It is also important to consider providing a lane or footpath for children circulation to reach the playing area. In addition, the construction of street is no longer good and uneven. Pointed bump of street materials can be seen in most of the circulation area. This condition may cause children to fall or get slippery. The natural movement of children that is dynamic and spontaneous is difficult to control with rhythmic and controllable walking or running pattern. Thus, facilities should be prepared, anticipated, and adjusted with unconsciousness of children behavior while playing.

In the context of playing facilities for the children, Kampung Badran has tried to fulfill the playing facilities with various tools. The availability of gazebo as shading becomes the magnitude for children gathering with some components of games that complete the gazebo. swings, slides, and other playing facilities are the effort of Kampung Badran to provide playing tools for the children in the kampung. However, the size of the tools has not fully considered the aspect of age and playing phase so the comfortableness to move for children in the lowest phase has not been fully accommodated. In addition, the condition of construction, wooden materials, metals, paint, etc. has shown obsoleteness that may potentially hurt and trap the children while using the facilities. Therefore, the facilities should be built systematically and conceptually by considering the open air location that make it exposed to the threat of sun and rain.

Participatory based treatment may be considered to address the problem. The involvement of local community in maintaining the playing facilities becomes urgent and to reach local community awareness to achieve sense of belonging can be nurtured through participation and contribution of power, ideas, time, and finance.

\section{Conclusion and Recommendation}

The characters of Children Friendly Kampung have been developed in Kampung Badran. However, the sustainability challenge for the kampung is how to maintain, improve, and enliven the characters. Maintenance and treatment towards the component for children friendly character has been inevitable and a must for stakeholders in order to keep the spirit to respect and develop children right in systemic and sustainable way. Kampung Badran as the pioneer of CFK attribute has potential as-sets and stakeholders. This potential can be optimized to make Badran role model for other kampung. The potential of the stakeholders is the availability of urban designer, residential, and social expert. The role of Yogyakarta as City of Students provides the assets of scientists and scholars that can be involved as the partner in development.

Strategic location of Kampung Badran in the city of Yogyakarta is potential asset that should be developed. Kampung Badran should also consider investment when economic support is needed. Shared interest of the stakeholders can be the option to develop Kampung Badran 
as long as each party has the same willingness to do development with the principle of proportionality and true justice.

\section{Reference}

Ambiyak, Moch. Irsyad. (2011). Efektivitas Permainan Konstruktif Keping Padu terhadap Peningkatan Kemampuan Motorik Halus Siswa TK Al-Kahfi Ds. Pilang Kec. Wonoayu Kab. Sidoarjo. Tugas Akhir. UIN Sunan Ampel Surabaya.

Aprilian, (2015), Sejarah Kampung Ramah Anak RW 02 Bener Tegalrejo Yogyakarta. http://kampungramahanakrw2bener. blogspot.co.id. Diakses pada tanggal 27 Oktober 2015

Baskara, Medha, (2009), Prinsip Pengendalian Perancangan Taman Bermain Anak di Ruang Publik. Jurnal Lansekap Indonesia Vol. 3 (1): 27-34.

Diyanti, Ayu O. et al, (2014), Lingkungan Ramah Anak pada Sekolah Taman Kanakkanak. Jurnal RUAS Vol. 12 (2): 54-68

Himawati, Ika Pasca, (2013), Konstruksi Sosial Kampung Ramah Anak: Studi Fenomenologi atas Implementasi Program Kampung Ramah Anak di RW 11 Kampung Badran Yogyakarta, Thesis S2 UGM
Hutapea, Ronggur Christopher et al, (2015), Taman Bermain Anak Dengan penekanan Aspek Keamanan dan Kenyamanan Di Tarekot Malang, Jurnal Mahasiswa Jurusan Arsitektur Brawijaya Vol 3, No.3.

Kharisma, Fajar, (2015). Kampung Badran Sebagai Kampung Ramah Anak Untuk Mewujudkan Yogyakarta Kota Layak Anak. Jurnal Sosiologi jpso-siologidd 150308.

Saptorini \& Apricilianingtyas. (2015). Location and access to the playing area.

Lutfiani, Sharfiah, (2015), Karakteristik dan Penggunaan Ruang Bermain di Kampung Badran Yogyakarta, Thesis S2 UGM.

Masiming, Zulfitriah. (2009), Pengaruh Setting Ruang Bermain Terhadap Perkembangan Kreativitas Anak Usia Dini. Jurnal SMARTek Vol. 7 (3): 184-196.

Wonoseputro, Christine. (2007). Ruang Publik sebagai Tempat Bermain Bagi AnakAnak Studi Kasus Pengembangan "The Urban Zoo" bagi Kawasan Pecinan di Singapura. Jurnal Dimensi Arsitektur. 